\title{
Aequorin Based Functional Assessment of the Melanin Concentrating Hormone Receptor by Intracellular Calcium Mobilization
}

\author{
Sunghou LEE* \\ Department of Biomedical Technology, Sangmyung University, Cheonan 330-720, Republic of Korea
}

(Received March 24, 2010; Revised April 1, 2010; Accepted April 2, 2010)

\begin{abstract}
Melanin concentrating hormone is a neuropeptide highly expressed in the brain that regulates several physiological functions mediated by receptors in the G-protein coupled receptor family, especially plays an important role in the complex regulation of energy balance and body weight mediated by the melanin concentrating hormone receptor subtype $1(\mathrm{MCH} 1)$. Compelling pharmacological evidence implicating $\mathrm{MCH} 1$ signaling in the regulation of food intake and energy expenditure has generated a great deal of interest by pharmaceutical companies as $\mathrm{MCH} 1$ antagonists may have potential therapeutic benefit in the treatment of obesity and metabolic syndrome. Although fluorescence-based calcium mobilization assay platform has been one of the most widely accepted tools for receptor research and drug discovery, fluorescence interference and shallow assay window limit their application in high throughput screening and have led to a growing interest in alternative, luminescence-based technologies. Herein, a luminescence-based functional assay system for the $\mathrm{MCH} 1$ receptor was developed and validated with the mitochondrial targeted aequorin. Aequorin based functional assay system for $\mathrm{MCH} 1$ presented excellent $Z^{\prime}$ factor (0.8983) and high signal-to-noise ratio (141.9). The nonpeptide MCH1 receptor antagonist, SNAP 7941 and GSK 803430 , exhibited $\mathrm{IC}_{50}$ values of $0.62 \pm 0.11$ and $12.29 \pm 2.31 \mathrm{nM}$ with excellent correlation coefficient. These results suggest that the aequorin based assay system for $\mathrm{MCH} 1$ is a strong alternative to the traditional GPCR related tools such as radioligand binding experiments and fluorescence functional determinations for the compound screening and receptor research.
\end{abstract}

Keywords: Melanin concentrating hormone, $\mathrm{MCH} 1$, Aequorin, High throughput screening, Calcium mobilization

\section{INTRODUCTION}

Melanin concentrating hormone $(\mathrm{MCH})$ is a cyclic 19 amino acid polypeptide produced predominantly by neurons in the brain, specifically expressed in the perikarya of the lateral hypothalamic area (LHA) and the zona incerta (ZI) projecting widely throughout the central nervous system (Vaughan et al., 1989; Bittencourt et al., 1992). The effects of $\mathrm{MCH}$ are mediated through two receptors that have been identified in humans, $\mathrm{MCH}$ receptor subtype 1 (MCH1, Chambers et al., 1999) and subtype 2 (MCH2, Hill et al., 2001). MCH1, a G protein coupled receptor (GPCR) previously known as orphan receptor SLC-1, was identified by several groups using different pharmacological ap-

${ }^{*}$ Corresponding author

Tel: +82-41-550-5388 Fax: +82-41-550-5184

E-mail: sunghou.lee@gmail.com proaches (Bachner et al., 1999; Chambers et al., 1999; Lembo et al., 1999; Saito et al., 1999). With the highest degree of homology to the somatostatin receptor family, $\mathrm{MCH} 1$ is highly conserved between human and rodents, and expressed in the brain regions where $\mathrm{MCH}$ fibers were identified in particular centers modulating feeding behavior (Bittencourt et al., 1992; Saito et al., 2001). On the other side, $\mathrm{MCH} 2$ receptor was identified on the basis of its sequence similarity to $\mathrm{MCH} 1$ and is absent in many species particularly in rodents (Tan et al., 2002). The distribution of $\mathrm{MCH} 2$ in the central nervous system suggests that it may mediate physiology similar to $\mathrm{MCH} 1$, however the physiological importance of $\mathrm{MCH} 2$ is difficult to assess because of its absence in rodent models.

$\mathrm{MCH} 1$ receptor antagonists have been shown to be effective at modulating feeding and diet induced obesity (Borowsky et al., 2002; Shearman et al., 2003; Kowalski 
and McBriar, 2004; Mashiko et al., 2005; Kowalski et al., 2006). Consistent with the wide distribution of $\mathrm{MCH} 1$ receptor in the brain, the $\mathrm{MCH}$ system is expected to be involved in various physiological functions and the $\mathrm{MCH}$ receptor antagonist has been shown to have antidepressant and anxiolytic activity (Borowsky et al., 2002; Chaki et al., 2005; Georgescu et al., 2005; Shimazaki et al., 2006; Smith et al., 2006; David et al., 2007). The compelling genetic and pharmacological evidence implicating $\mathrm{MCH} 1$ signaling in the regulation of food intake and energy expenditure has generated a great deal of interest by pharmaceutical companies for the discovery of $\mathrm{MCH} 1$ antagonists, evidenced by the increased number of patents describing $\mathrm{MCH} 1$ antagonists for the treatment of obesity and metabolic syndrome (Kowalski and McBriar, 2004).

Currently, the increasing numbers of diverse small molecules generated through combinatorial chemistry (Pinilla et al., 2003) together with novel molecular targets identified from genomics efforts necessitates the use of highthroughput assays with a good sensitivity and specificity for use as a high throughput screening (HTS) program (Burbaum and Sigal, 1997). Especially, for the research of the GPCR targets, changes in the level of cytoplasmic calcium can be measured and used as a surrogate of receptor activity enabled by advances in fluorescence dye based methodologies. One extremely sensitive and versatile technology that could serve broadly as a replacement for the use of a fluorescent signal is based on the luminescence measurements by the use of aequorin (Walstab et al., 2007; Gilchrist et al., 2008; Brough and Shah, 2009). The aequorin-based receptor functional assay system is one of the most powerful tools for the GPCR research and drug discovery for the screening of various compounds without possible fluorescence interference by compounds itself. However, because of the technology barrier required by the intellectual property issue such as licensing costs, the use of aequorin is very limited in academic sector comparing to global pharmaceutical industries. Currently, only few receptor systems are commercially available and still need a major expansion for the application of aequorin-based luminescence detection system in upcoming receptor targets for their research and drug discovery.

In this report, we described the development of an aequorin based functional assessment of the melanin concentrating hormone receptor by intracellular calcium mobilization employing the aequorin parental cell line for the first time in Korea as a HTS model system to generate diverse $\mathrm{MCH} 1$ receptor antagonists which will be useful to study physiological functions of the $\mathrm{MCH}$ system and help out research communities to develop a reliable screening tools for various receptor systems.

\section{MATERIALS AND METHODS}

\section{Materials}

The aequorin parental cell line (ES-000-A30) was licensed from PerkinElmer Life and Analytical Sciences (Boston, MA, USA). cDNA for MCH1 receptor (GenBank Acc\# AY562945) was from Missouri S\&T cDNA Resource Center (Rolla, USA) and the MCH (human, mouse, rat) was from Bachem Bioscience Inc. (King of Prussia, PA, USA). As standard compounds, SNAP 7941 (Borowsky et al., 2002) and GSK 803430 (Kowalski et al., 2006) were synthesized in the Bio-organic science division, Korea Research Institute of Chemical Technology (KRICT, Daejeon, Korea). Eagle's minimum essential medium was from Lonza Group Ltd. (Basel, Switzerland). Fetal bovine serum, antibiotics and Lipofectamine 2000 were purchased from Invitrogen Corporation (Carlsbad, CA, USA). 96-well white Optiplates were from PerkinEImer Life and Analytical Sciences (Boston, MA, USA), and 96-well compound plates were purchased from Greiner Bio-one $\mathrm{GmbH}$ (Frickenhausen, Germany). The chromophore cofactor, coelenterazine $\mathrm{h}$, for calcium mobilization assay was from Promega Corporation (Madison, WI, USA).

\section{Cell culture}

The aequorin parental cells were grown in Eagle's minimum essential medium supplemented with $10 \%$ fetal bovine serum, $100 \mathrm{IU} / \mathrm{ml}$ penicillin, $100 \mu \mathrm{g} / \mathrm{ml}$ streptomycin, and $10 \mu \mathrm{g} / \mathrm{ml}$ zeocin. Cells were cultured at $37^{\circ} \mathrm{C}$ under a humidified atmosphere containing $5 \% \mathrm{CO}_{2}$. To establish HEK293-aeq/hMCH1, a stable cell line for the human $\mathrm{MCH} 1$ receptor, the cDNA for $\mathrm{MCH} 1$ (GenBank Acc\# AY562945) in pcDNA3.1 $1^{+}$was transfected with Lipofectamine 2000 according to the manufacturer's instructions. During the clonal selection for the search of maximum calcium responses in transfected cells, the concentration of G418 was kept at $400 \mu \mathrm{g} / \mathrm{ml}$. To obtain reproducible $\mathrm{Ca}^{2+}$ responses, cells were split every 4 days before they became confluent. Cells were discarded after 2-3 months of continuous growth with splitting, and new cells were prepared from a frozen stock.

\section{Measurements of intracellular calcium mobilization}

A functional assay based on the luminescence of mitochondrial aequorin following intracellular calcium release was performed using HEK293-aeq/hMCH1 cells generated from the aequorin parental cell line (ES-000-A30). Briefly, HEK293-aeq/hMCH1 cells were grown in Eagle's 
minimum essential medium supplemented with $10 \%$ fetal bovine serum, $100 \mathrm{IU} / \mathrm{ml}$ penicillin, $100 \mu \mathrm{g} / \mathrm{ml}$ streptomycin, $10 \mu \mathrm{g} / \mathrm{ml}$ zeocin and $400 \mu \mathrm{g} / \mathrm{ml}$ G418. Cells were grown at mid-log phase without antibiotics 18 hours before the day of experiment and washed with PBS/5mM EDTA followed by gently detaching with DPBS/5 mM EDTA ( $\mathrm{pH}$ 7.4). Collected cells from culture plates were centrifuged and resuspended in assay buffer (DMEM/HAM's F12 without phenol red, with L-Glutamine, 15 mM HEPES, pH 7.0 and $0.1 \%$ BSA) at a density of $1 \times 10^{6}$ cells $/ \mathrm{ml}$.

Cells were incubated for 4 hours at room temperature in the dark with $5 \mu \mathrm{M}$ of coelenterazine $\mathrm{h}$ in a constant agitation. After the coelenterazine loading, cells were diluted in assay buffer at a concentration of $1 \times 10^{5}$ cells $/ \mathrm{ml}$ and incubated for $60 \mathrm{~min}$ as described above. For the agonist response, $50 \mu$ of cells (i.e., 5,000 cells) were injected over $50 \mu$ of agonists plated in 96 well Optiplates. The light emission was recorded for the determination of cell activation using EnVision excite model integrated with injectors (PerkinEImer Life and Analytical Sciences, Boston, MA, USA). The total light (AUC integrated signal) was used as a measurement of the response of the cells. Results were expressed as relative light units (RLU). For the measurement of antagonist activity, cells were pre-injected on the antagonist at the indicated dilutions and were incubated for $15 \mathrm{~min} .50 \mu \mathrm{l}$ of the reference agonist at a concentration equal to $2 \times$ the $\mathrm{EC}_{80}$ was then injected and the light emission was recorded for the determination of antagonistic effects.

\section{Screening chemical compounds for the $\mathrm{MCH} 1$ receptor antagonist}

As a pilot HTS campaign for the search of $\mathrm{MCH} 1$ receptor antagonist, 80 subset compounds generated through combinatorial chemistry program in KRICT was screened at a concentration of $10 \mu \mathrm{M}$ with the aequorin based assay technology. After the first round of screening, "Hits" were selected based on at least $80 \%$ inhibition of the experimental signal obtained in compound-free control wells. Random portions of compounds were screened in triplicate to demonstrate the reproducibility of assay format and the effects of dimethyl sulfoxide (DMSO) in these assay formats were confirmed in control experiments. Cherry- picked hit compounds were re-confirmed in triplicate experiments and excluded if any compounds did not present more than two-thirds of their activity above the initial guideline activity, followed by dose response analysis.

\section{Statistical analysis}

The data from dose-response experiments were ana- lyzed using the nonlinear curve fitting functions in PRISM version 5.0 (GraphPad Software Inc., San Diego, CA, USA). The classical equation for one site-competition binding for the nonlinear regression analysis was used. Other statistical data were expressed as the mean \pm SD and analyzed using Microsoft Excel (Microsoft Corporation, Redmond, USA).

\section{RESULTS}

\section{Control data and measurements of $\mathrm{MCH}$ response}

HEK293-aeq/hMCH1 cells were proved to be sensitive to $\mathrm{MCH}$ application and yielded reproducible increases in luminescence of up to 600,000 relative light units (RLU) according to the number of cells loaded (Fig. 1). The relation coefficient from a linear regression of response curve between maximal signals and cell numbers was 0.987 . The cell dose was set to 5,000 cells/well for the entire $\mathrm{MCH} 1$ receptor experiments because of the assay productivity and manageability. With this condition, the transient calcium signals by $\mathrm{MCH}$ were measured by the addition of $\mathrm{MCH}$ at various concentrations and the resulted $\mathrm{EC}_{50}$ was $15.83 \pm 1.77 \mathrm{nM}$ (Fig. 2). Nonlinear regression analysis of the sigmoidal dose response represented $r^{2}$ value of 0.9535 and 0.7473 for Hill slope factor. These ag-

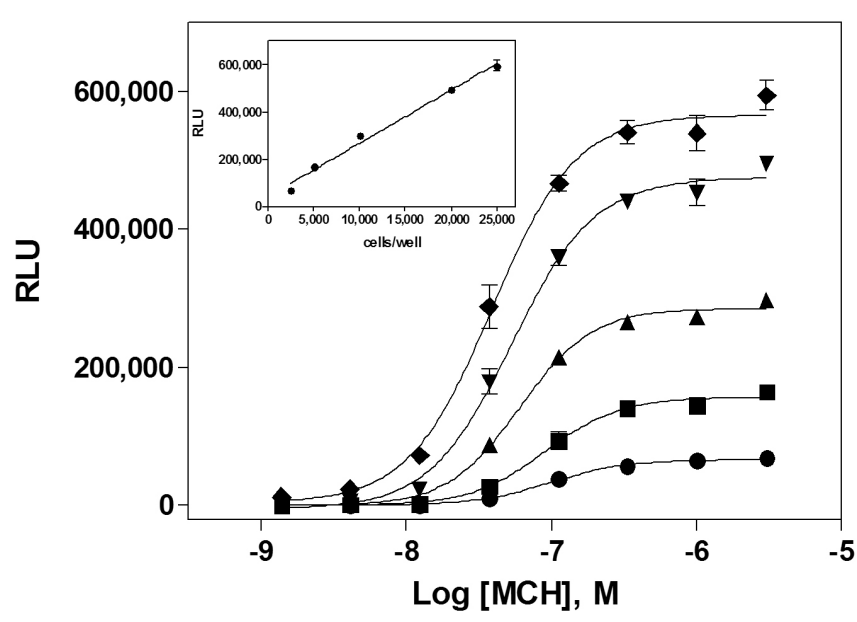

Fig. 1. Dose response curves for $\mathrm{MCH}$ based on cell numbers. $50 \mu \mathrm{l}$ of cells $(\mathbf{O}: 2,500, \mathbf{\square}: 5,000, \mathbf{\Delta}: 10,000, \boldsymbol{\nabla}: 20,000, \boldsymbol{\text { : }}$ 25,000 cells) were injected over $50 \mu \mathrm{l}$ of $\mathrm{MCH}(1 \mathrm{nM}-3 \mathrm{mM})$ plated in 96 well Optiplates. The total light (AUC integrated signal) was used as a measurement of the response of the cells and results were expressed as relative light units (RLU). Three separate experiments were run and the representative data from a single experiment were presented as mean $\pm \mathrm{SD}$. Inset showed the relationship between maximal signals and cell numbers. 


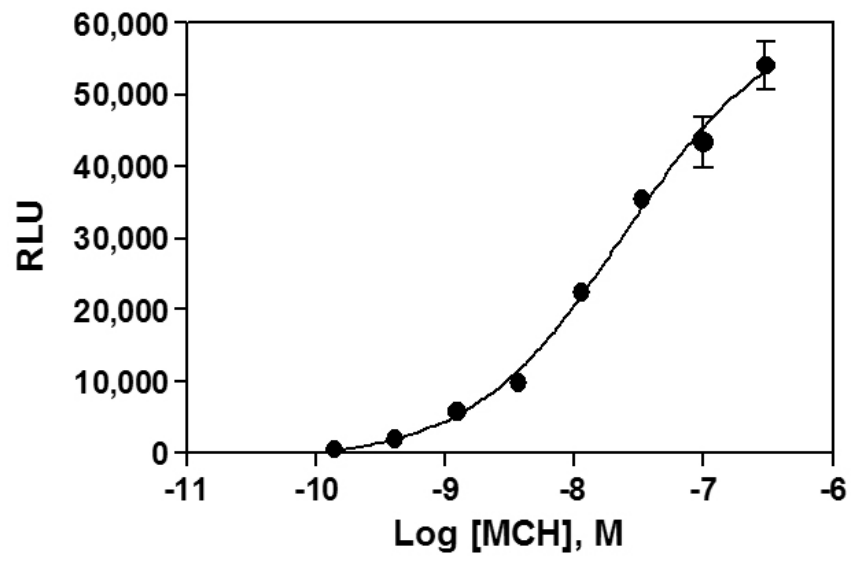

Fig. 2. Agonist response curve for $\mathrm{MCH}\left(\mathrm{EC}_{50}=15.83 \pm 1.77\right.$ $\mathrm{nM}) .50 \mu$ of cells were injected onto various concentrations of $\mathrm{MCH}(0.1 \mathrm{nM}-0.3 \mathrm{mM})$ with buffer controls after equilibration period. The total light (AUC integrated signal) was used as a measurement of the response of cells and results were expressed as relative light units (RLU). Data were presented as mean $\pm S D$, and plots were representative of twelve independent experiments.

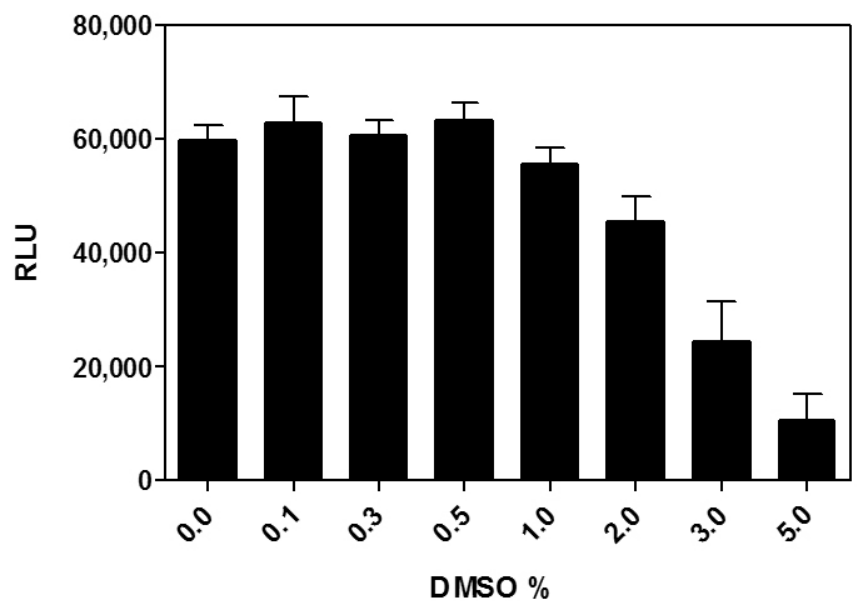

Fig. 3. The effects of DMSO on the functional assay for $\mathrm{MCH} 1$ receptor. An agonist control responses were generated with various concentrations of DMSO in assay mixture (0-5\%). The total light (AUC integrated signal) was used as a measurement of the response of cells by $100 \mathrm{nM}$ of $\mathrm{MCH}$ with injection of 5,000 cells into wells. Data were presented as mean \pm SD, and plots were representative of three independent experiments in triplicate.

onist responses were lasted for about 10 seconds right after the addition of cells and the maximum luminescence signal was reached at 3-5 second interval.

\section{Measurements of antagonist response}

Because cell-based screening of chemical compounds

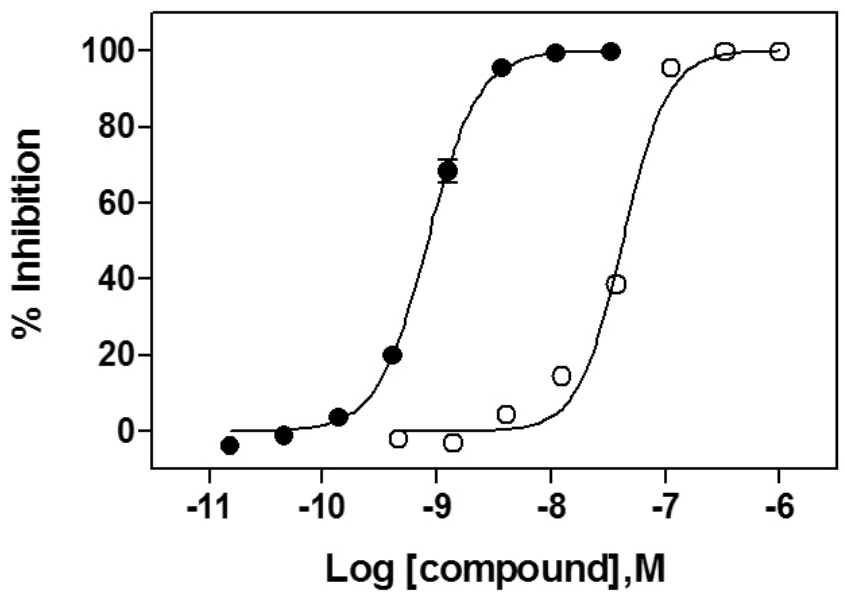

Fig. 4. Antagonist dose response of SNAP 7941 and GSK 803430. Antagonist control responses curves were generated for SNAP $7941\left(O, I C_{50}=0.62 \pm 0.11 \mathrm{nM}\right)$ and GSK $803430(\bigcirc$, $\left.\mathrm{IC}_{50}=12.29 \pm 2.31 \mathrm{nM}\right)$. Various concentrations of SNAP 7941 $(0.01-10 \mathrm{nM})$ and GSK $803430(0.3 \mathrm{nM}-1 \mu \mathrm{M})$ were added 15 min before the addition of $50 \mathrm{ml}$ of agonist (100 nM of MCH) and integrated light signals were measured for the total of $15 \mathrm{~s}$ time frame. The percent of inhibition data were based on positive controls (assay buffer, DMEM/HAM's F12 without phenol red, with L-Glutamine, $15 \mathrm{mM}$ HEPES, pH 7.0 and $0.1 \% \mathrm{BSA}$ ) and negative control values (333 nM of SNAP 7941). Data were presented as mean $\pm S D$, and plots were representative of six independent experiments.

is typically conducted in the presence of low concentrations of dimethyl sulfoxide (DMSO, aids in compound solubility), the effects of DMSO on the MCH1 functional assay system were investigated. Concentrations of DMSO as high as $1 \%$ had no effect on the assay performance as judged by the negative and positive control values (Fig. 3). Increasing concentrations of DMSO yielded significant decrease of agonist responses $(59 \%, 82 \%$ decrease in $3 \%$ and $5 \%$ DMSO, respectively). Based on these data, a final concentration of $0.5 \%$ DMSO was chosen for the development of the $\mathrm{MCH} 1$ functional assay system for compounds.

Two standard compounds, SNAP 7941 and GSK 803430, were tested for their antagonistic response in our HEK293-aeq/hMCH1. At our experimental conditions, both compounds inhibited agonistic activities by $\mathrm{MCH}$ (human, mouse, rat) in a dose dependent fashion (Fig. 4). The $\mathrm{IC}_{50}$ values from dose response assays with fixed $\mathrm{MCH}$ concentration (100 nM) were $0.62 \pm 0.11 \mathrm{nM}$ for SNAP 7941 and $12.29 \pm 2.31 \mathrm{nM}$ for GSK 803430 . Excellent correlation coefficients were obtained in both experiments (0.9768 for SNAP 7941, 0.9680 for GSK 803430), and the Hill slopes were evaluated as 1.958 for SNAP 7941, and 


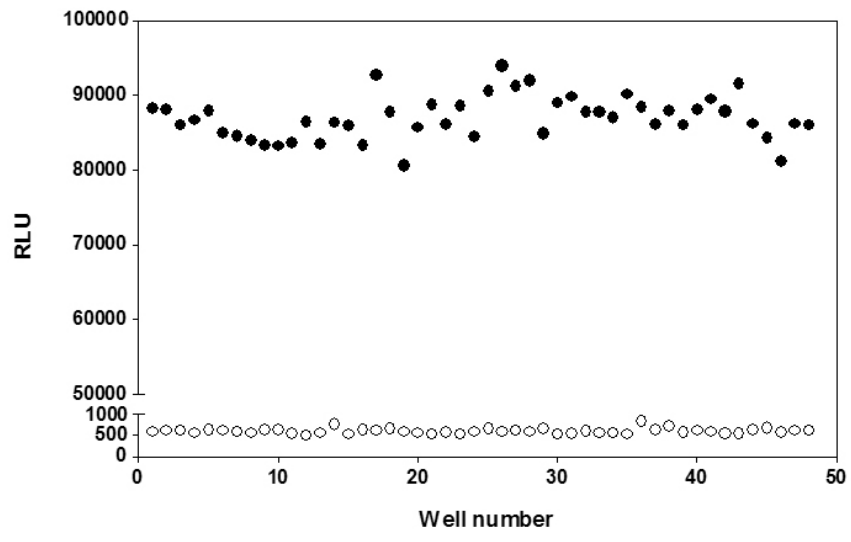

Fig. 5. Determination of the variation in negative and positive control values. Positive and negative control responses were compared for the determination Z' factor. $50 \mu$ of agonist (100 $\mathrm{nM}$ of $\mathrm{MCH}$ ) was added onto 5,000 cells incubated for 15 min with assay buffer (DMEM/HAM's F12 without phenol red, with L-Glutamine, $15 \mathrm{mM}$ HEPES, pH 7.0 and $0.1 \%$ BSA) or $333 \mathrm{nM}$ of SNAP 7941. Integrated light signals were measured for the total of $15 \mathrm{sec}$ time frames and data values from a single plate were presented. Plots were representative of three independent experiments.

\subsection{9 for GSK 803430.}

\section{Pilot screening of chemical compounds}

To determine the variation of negative and positive control values, three 96-well plates were run to calculate $Z^{\prime}$ values as an indication of assay robustness (Zhang et al., 1999). As shown in Fig. 5, the AUC integrated signal values presented clear separations of the negative and positive control values $(613 \pm 65$ and $86,987 \pm 2,863$, respectively) with $Z$ ' value of 0.8983 . From those negative and positive control data in 96 well validation experiments, signal-to-noise ratio was calculated as high as 141.9 , indicating that the current assay can be used to generate high quality screening data for chemical compounds. This extremely high signal-to-noise ratio was due to the low background negative control signals.

As a pilot HTS campaign for the search of $\mathrm{MCH} 1$ receptor antagonist, 80 subset compounds generated through combinatorial chemistry program in KRICT was screened at a concentration of $10 \mu \mathrm{M}$ on the aequorin based assay technology (Fig. 6). Negative controls were set with $333 \mathrm{nM}$ of SNAP 7941 and resulting luminescence signals by $100 \mathrm{nM}$ of $\mathrm{MCH}$ were recorded in each compound. The pattern of screening data showed reproducible results in separate experiments with average $\mathrm{SD}$ of 5.7. After the first round of screening, selected compounds were processed for further experiments.

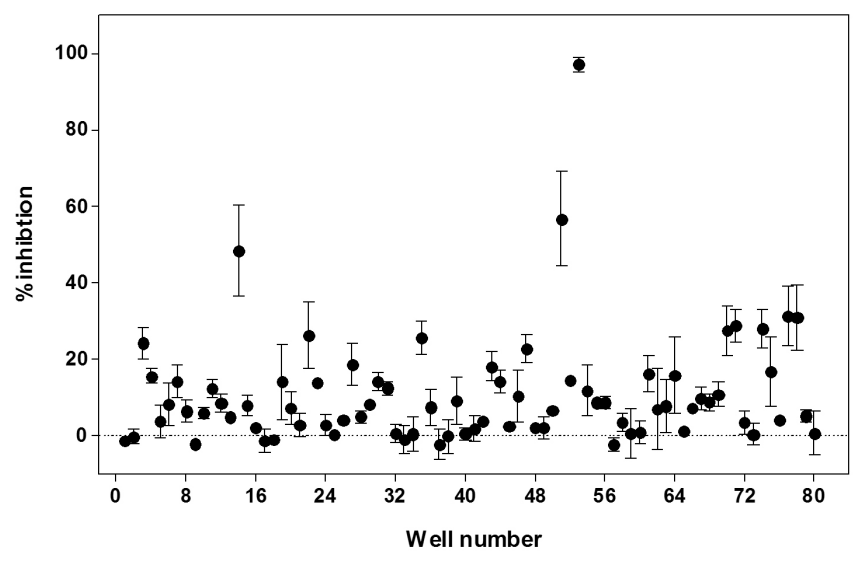

Fig. 6. Pilot screening of 80 chemical compounds selected from a target library. Control wells containing equivalent amount of DMSO as compounds were in columns 1 and 2. Compounds were present at a final concentration of $10 \mu \mathrm{M}$ in each well of columns 3 through 12. The negative control group was defined with $333 \mathrm{nM}$ of SNAP 7941. Data were presented as mean \pm SD from results in three separate assay plates.

\section{DISCUSSION}

The central role of $\mathrm{Ca}^{2+}$ in intracellular signaling makes it a very attractive reporter for the process of drug discovery. Many of the most interesting target classes for the pharmaceutical industry, such as GPCRs, ion channels, and transporters, trigger a $\mathrm{Ca}^{2+}$ mobilization upon activation (Rink, 1990). Determination of the activity of targets by measurement of increased intracellular $\mathrm{Ca}^{2+}$ concentration is now a very common approach, and the development of more sensitive technologies for the measurement of $\mathrm{Ca}^{2+}$ concentration has long been a matter of interest. The first $\mathrm{Ca}^{2+}$ mobilization assays were developed using fluorescence intensity by complex formation with $\mathrm{Ca}^{2+}$ and their use for HTS was limited until the development of the fluorometric imaging plate reader (FLIPR). Althrough the use of fluorescent probes has become very common in HTS, their use is complicated by the inherent fluorescence of dye loaded cells and interference by compounds itself.

To overcome current limitations with fluorescence applications, use of photoproteins to sense intracellular $\mathrm{Ca}^{2+}$ concentrations more effectively have been developed (Hedley et al., 1996; Stables et al., 1997; Dupriez et al., 2002; Le Poul et al., 2002; Bovolenta et al., 2007). Most recently, the aequorin parental cell line was licensed from PerkinElmer (ES-000-A30) through previous collaborative research program with Euroscreen S.A. (Brussels, Belgium). From this well established system, we have gen- 
erated HEK293-aeq/hMCH1 cells as an aequorin based assay system for the measurement of intracellular $\mathrm{Ca}^{2+}$ concentrations in the $\mathrm{MCH} 1$ receptor and tested its reliability for the screening of $\mathrm{MCH} 1$ receptor antagonists.

As shown in Fig. 1, the $\mathrm{MCH}$ (human, mouse, rat) presented dose dependent agonist response with various cell numbers. The agonist response showed an excellent correlation with cell numbers and optimum assay window of around 100 was reached at 5,000 cells per well. The $\mathrm{EC}_{50}$ of $\mathrm{MCH}(15.83 \pm 1.77 \mathrm{nM})$ was similar with results from FLIPR experiments (Wang et al., 2001) suggesting that our aequorin based assay system can achieve the desired sensitivities to replace the fluorescence-based calcium mobilization assay system. Considering the nature of this assay technology, cell suspension procedure followed by the coelenterazine loading would be very critical to ensure the best possible signal and assay reproducibility. To confirm methods for detaching cells, various treatment controls with PBS/5 mM EDTA, Detachin (Genlantis, San Diego, USA) and trypsin were tested. Cell treatments with PBS/5 mM EDTA and Detachin showed a similar agonist response by $\mathrm{MCH}\left(\mathrm{EC}_{50}\right.$ : $17.78 \mathrm{nM}$ and $8.68 \mathrm{nM}$, respectively), however, $0.5 \%$ trypsin treatment resulted a significant decrease affecting the robustness of control data. Therefore, it was suggested that Detachin can be used to facilitate getting a homogeneous cell suspension before the coelenterazine loading.

Regarding the vehicle compatibility in our aequorin based assay system, the effects of DMSO were needed to be robustly resistant to a final assay concentration to be able to screen compounds at sufficiently high concentrations for hit identification purposes. Our Aequorin assay system tolerated final concentrations of DMSO in excess of $1 \%$ which is regarded as a benchmark of acceptability. Finally, to access our assay system for the $\mathrm{MCH} 1$ receptor, random selection of compounds from the combinatorial chemistry compound library were screened in a 96-well plate format. Statistical data showed that the degree of data fluctuation in control values was very low and the signal-to-noise ratio was more than 120 with an excellent reproducibility (Fig. 6), suggesting that our aequorin based assay system is robust and well fit into HTS campaigns for drug discovery efforts.

The present study demonstrates an aequorin based luminescence assay that is sensitive, reproducible, and capable of screening human $\mathrm{MCH} 1$ receptor antagonists in high throughput format. Together with possibility of the transient expression for the fast tracking of target receptors and implementation of stocked frozen cells, the aequorin based functional assay system for $\mathrm{MCH} 1$ is a strong alternative to the traditional GPCR related tools such as radioligand binding experiments and fluorescence functional determinations for the compound screening and receptor research.

\section{ACKNOWLEDGMENTS}

This work was supported by the grants from the Center for Biological Modulators of the 21C Frontier R\&D Program (CBM32-B4001-01-01-00) and from the National Research Foundation of Korea Grant (KRF-2008-331-E00019), the Ministry of Education, Science and Technology.

\section{REFERENCES}

Bachner, D., Kreienkamp, H., Weise, C., Buck, F. and Richter, D. (1999). Identification of melanin concentrating hormone $(\mathrm{MCH})$ as the natural ligand for the orphan somatostatin-like receptor 1 (SLC-1). FEBS Lett. 457, 522-524.

Bittencourt, J. C., Presse, F., Arias, C., Peto, C., Vaughan, J., Nahon, J. L., Vale, W. and Sawchenko, P. E. (1992). The melanin-concentrating hormone system of the rat brain: an immuno- and hybridization histochemical characterization. $J$. Comp. Neurol. 319, 218-245.

Borowsky, B., Durkin, M. M., Ogozalek, K., Marzabadi, M. R., DeLeon, J., Lagu, B., Heurich, R., Lichtblau, H., Shaposhnik, Z., Daniewska, I., Blackburn, T. P., Branchek, T. A., Gerald, C., Vaysse, P. J. and Forray, C. (2002). Antidepressant, anxiolytic and anorectic effects of a melanin-concentrating hormone-1 receptor antagonist. Nat. Med. 8, 825-830.

Bovolenta, S., Foti, M., Lohmer, S. and Corazza, S. (2007). Development of a $\mathrm{Ca}(2+)$-activated photoprotein, Photina, and its application to high-throughput screening. J. Biomol. Screen 12, 694-704.

Brough, S. J. and Shah, P. (2009). Use of aequorin for G protein-coupled receptor hit identification and compound profiling. Methods Mol. Biol. 552, 181-198.

Burbaum, J. J. and Sigal, N. H. (1997). New technologies for high-throughput screening. Curr. Opin. Chem. Biol. 1, 72-78.

Chaki, S., Yamaguchi, J., Yamada, H., Thomsen, W., Tran, T. A., Semple, G. and Sekiguchi, Y. (2005). ATC0175: an orally active melanin-concentrating hormone receptor 1 antagonist for the potential treatment of depression and anxiety. CNS Drug Rev. 11, 341-352.

Chambers, J., Ames, R. S., Bergsma, D., Muir, A., Fitzgerald, L. R., Hervieu, G., Dytko, G. M., Foley, J. J., Martin, J., Liu, W. S., Park, J., Ellis, C., Ganguly, S., Konchar, S., Cluderay, J., Leslie, R., Wilson, S. and Sarau, H. M. (1999). Melaninconcentrating hormone is the cognate ligand for the orphan G-protein-coupled receptor SLC-1. Nature 400, 261-265.

David, D. J., Klemenhagen, K. C., Holick, K. A., Saxe, M. D., Mendez, I., Santarelli, L., Craig, D. A., Zhong, H., Swanson, C. J., Hegde, L. G., Ping, X. I., Dong, D., Marzabadi, M. R., Gerald, C. P. and Hen, R. (2007). Efficacy of the MCHR1 antagonist $\mathrm{N}$-[3-(1-\{[4-(3,4-difluorophenoxy)phenyl]methyl\} (4-piperidyl))-4-methylphen yl]-2-methylpropanamide (SNAP 94847 ) in mouse models of anxiety and depression following 
acute and chronic administration is independent of hippocampal neurogenesis. J. Pharmacol. Exp. Ther. 321, 237248.

Dupriez, V. J., Maes, K., Le Poul, E., Burgeon, E. and Detheux, M. (2002). Aequorin-based functional assays for G-proteincoupled receptors, ion channels, and tyrosine kinase receptors. Recept. Channels 8, 319-330.

Georgescu, D., Sears, R. M., Hommel, J. D., Barrot, M., Bolanos, C. A., Marsh, D. J., Bednarek, M. A., Bibb, J. A., Maratos-Flier, E., Nestler, E. J. and DiLeone, R. J. (2005). The hypothalamic neuropeptide melanin-concentrating hormone acts in the nucleus accumbens to modulate feeding behavior and forced-swim performance. J. Neurosci. 25 , 2933-2940.

Gilchrist, M. A. 2nd, Cacace, A. and Harden, D. G. (2008). Characterization of the $5-\mathrm{HT} 2 \mathrm{~b}$ receptor in evaluation of aequorin detection of calcium mobilization for miniaturized GPCR high-throughput screening. J. Biomol. Screen 13, 486-493.

Hedley, L., Phagoo, S. B. and James, I. F. (1996). Measurement of intracellular calcium in cell populations loaded with aequorin: neurokinin-1 responses in U373MG cells. Anal. Biochem. 236, 270-274.

Hill, J., Duckworth, M., Murdock, P., Rennie, G., Sabido-David, C., Ames, R. S., Szekeres, P., Wilson, S., Bergsma, D. J., Gloger, I. S., Levy, D. S., Chambers, J. K. and Muir, A. I. (2001). Molecular cloning and functional characterization of $\mathrm{MCH} 2$, a novel human $\mathrm{MCH}$ receptor. J. Biol. Chem. 276 20125-20129.

Kowalski, T. J. and McBriar, M. D. (2004). Therapeutic potential of melanin-concentrating hormone-1 receptor antagonists for the treatment of obesity. Expert Opin. Investig. Drugs 13, 1113-1122.

Kowalski, T. J., Spar, B. D., Weig, B., Farley, C., Cook, J., Ghibaudi, L., Fried, S., O'Neill, K., Del Vecchio, R. A., McBriar, M., Guzik, H., Clader, J., Hawes, B. E. and Hwa, J. (2006). Effects of a selective melanin-concentrating hormone 1 receptor antagonist on food intake and energy homeostasis in diet-induced obese mice. Eur. J. Pharmacol. 535, 182-191.

Le Poul, E., Hisada, S., Mizuguchi, Y., Dupriez, V. J., Burgeon, E. and Detheux, M. (2002). Adaptation of aequorin functional assay to high throughput screening. J. Biomol. Screen 7 , 57-65.

Lembo, P. M., Grazzini, E., Cao, J., Hubatsch, D. A., Pelletier, M., Hoffert, C., St-Onge, S., Pou, C., Labrecque, J., Groblewski, T., O'Donnell, D., Payza, K., Ahmad, S. and Walker, P. (1999). The receptor for the orexigenic peptide melanin-concentrating hormone is a G-protein-coupled receptor. Nat. Cell Biol. 1, 267-271.

Mashiko, S., Ishihara, A., Gomori, A., Moriya, R., Ito, M., Iwaasa, H., Matsuda, M., Feng, Y., Shen, Z., Marsh, D. J., Bednarek, M. A., MacNeil, D. J. and Kanatani, A. (2005). Antiobesity effect of a melanin-concentrating hormone 1 receptor antagonist in diet-induced obese mice. Endocrinology 146, 3080-3086.

Pinilla, C., Appel, J. R., Borras, E. and Houghten, R. A. (2003).
Advances in the use of synthetic combinatorial chemistry: mixture-based libraries. Nat. Med. 9, 118-122.

Rink, T. J. (1990). Receptor-mediated calcium entry. FEBS Lett. 268, 381-385.

Saito, Y., Nothacker, H. P., Wang, Z., Lin, S. H., Leslie, F. and Civelli, O. (1999). Molecular characterization of the melaninconcentrating-hormone receptor. Nature 400, 265-269.

Saito, Y., Wang, Z., Hagino-Yamagishi, K., Civelli, O., Kawashima, S. and Maruyama, K. (2001). Endogenous melaninconcentrating hormone receptor SLC-1 in human melanoma SK-MEL-37 cells. Biochem. Biophys. Res. Commun. 289, 44-50.

Shearman, L. P., Camacho, R. E., Sloan Stribling, D., Zhou, D. Bednarek, M. A., Hreniuk, D. L., Feighner, S. D., Tan, C. P., Howard, A. D., Van der Ploeg, L. H., Maclntyre, D. E., Hickey, G. J. and Strack, A. M. (2003). Chronic MCH-1 receptor modulation alters appetite, body weight and adiposity in rats. Eur. J. Pharmacol. 475, 37-47.

Shimazaki, T., Yoshimizu, T. and Chaki, S. (2006). Melaninconcentrating hormone $\mathrm{MCH} 1$ receptor antagonists: a potential new approach to the treatment of depression and anxiety disorders. CNS Drugs 20, 801-811.

Smith, D. G., Davis, R. J., Rorick-Kehn, L., Morin, M., Witkin, J. M., McKinzie, D. L., Nomikos, G. G. and Gehlert, D. R. (2006). Melanin-concentrating hormone-1 receptor modulates neuroendocrine, behavioral, and corticolimbic neurochemical stress responses in mice. Neuropsychopharmacology 31, 1135-1145

Stables, J., Green, A., Marshall, F., Fraser, N., Knight, E., Sautel, M., Milligan, G., Lee, M. and Rees, S. (1997). A bioluminescent assay for agonist activity at potentially any G-protein-coupled receptor. Anal. Biochem. 252, 115-126.

Tan, C. P., Sano, H., Iwaasa, H., Pan, J., Sailer, A. W., Hreniuk, D. L., Feighner, S. D., Palyha, O. C., Pong, S. S., Figueroa, D. J., Austin, C. P., Jiang, M. M., Yu, H., Ito, J., Ito, M., Ito, M., Guan, X. M., MacNeil, D. J., Kanatani, A., Van der Ploeg, L. H. and Howard, A. D. (2002). Melanin-concentrating hormone receptor subtypes 1 and 2: species-specific gene expression. Genomics 79, 785-792.

Vaughan, J. M., Fischer, W. H., Hoeger, C., Rivier, J. and Vale, W. (1989). Characterization of melanin-concentrating hormone from rat hypothalamus. Endocrinology 125, 1660-1665.

Walstab, J., Combrink, S., Bruss, M., Gothert, M., Niesler, B. and Bonisch, H. (2007). Aequorin luminescence-based assay for 5-hydroxytryptamine (serotonin) type 3 receptor characterization. Anal. Biochem. 368, 185-192.

Wang, S., Behan, J., O'Neill, K., Weig, B., Fried, S., Laz, T., Bayne, M., Gustafson, E. and Hawes, B. E. (2001). Identification and pharmacological characterization of a novel human melanin-concentrating hormone receptor, mch-r2. J. Biol. Chem. 276, 34664-34670.

Zhang, J. H., Chung, T. D. and Oldenburg, K. R. (1999). A Simple Statistical Parameter for Use in Evaluation and Validation of High Throughput Screening Assays. J. Biomol. Screen 4, 67-73. 